\title{
PROGNOSTIC SIGNIFICANCE OF BLOOD MARKER OF HYPERTROPHY- CARDIOTROPHIN-1 WHEN CARRYING DIFFERENT VARIANTS OF ITS GENE IN MEN WITH ESSENTIAL HYPERTENSION
}

D0l:10.36740/WLek202102118

\author{
Maryna O. Matokhniuk, Oleksandr V. Limanskiy, Olena V. Maiko, Vadym Zhebel, Oleksandra K. Shevchuk, Irina K. Palii \\ VINNYTSIA NATIONAL PIROGOV MEMORIAL MEDICAL UNIVERSITY, VINNYTSIA, UKRAINE
}

\begin{abstract}
The aim: To improve diagnosis of essential hypertension with left ventricular hypertrophy and chronic heart failure in men citizens of Podillya region in Ukraine by determining the plasma levels of cardiotrophin-1 in patients with different $\mathrm{CT}-1$ gene variants.

Materials and methods: A total of 70 men with no signs of cardiovascular disease and 100 patients with essential hypertension were examined. Among those, 50 participants had hypertension and left ventricular hypertrophy. Other 50 patients had hypertension complicated by chronic heart failure.

Results: It was established that in patients with essential hypertension the frequency of the pool of genotypes GA + AA is higher than the genotype GG $(p<0.05)$. Plasma CT-1 levels $\geq 122,895 \mathrm{pg} / \mathrm{ml}$ can be used for early diagnosis left ventricular hypertrophy, and the cut-off level is $\geq 303.81 \mathrm{pg} / \mathrm{ml}$ (sensitivity $85.7 \%$, specificity $92 \%$ ) for screening diagnosis of essential hypertension complications in the form of chronic heart failure.

Conclusions: In patients with essential hypertension of varying severity, the GA+AA genotypes of CT-1 gene was found to be dominant. They had higher levels of plasma concentration CT-1. The threshold levels of CT-1 for screening diagnosis of essential hypertension with hypertrophy and chronic heart failure in males (who were residents of the Podillya region of Ukraine) were evaluated.
\end{abstract}

KEY WORDS: Cardiotrophin-1, essential hypertension, left ventricular hypertrophy, chronic heart failure, polymorphism of cardiotrophin-1 gene

Wiad Lek. 2021;74(2):273-277

\section{INTRODUCTION}

According to the Framingham study, the presence of left ventricular hypertrophy ( $\mathrm{LVH})$ doubles the incidence of cardiovascular events. An increase in LV wall thickness in patients with essential hypertension $(\mathrm{EH})$ by $1 \mathrm{~mm}$ can be associated with an increased risk of dying by 7 times. The significance of myocardial hypertrophy as an independent predictor of cardiovascular complications in $\mathrm{EH}$ when assessing myocardial viability has been proved. [1,2].

At a certain stage of $\mathrm{LVH}$ development myocardial fibrosis and a number of other pathomorphological ones begin to form shifts, which ultimately lead to myocardial dysfunction and heart failure (CHF), which results in frequent hospitalizations and increased mortality of people with EH. This encourages the search for biomarkers for accurate diagnosis of LVH and prediction of CHF, especially in the early stages of the disease. Finding a solution to this problem requires an assessment of both the state of myocytes and myocardial connective tissue. One of the biomarkers that can help answer the above questions is cardiotrophin-1 (CT-1).

CT-1 is a member of the superfamily of cytokines interleukin IL- 6 and is considered as one of the key regulators of hypertrophy and cardiomyocyte hyperplasia. CT-1 also affects the intensity of apoptosis and myocardial sensitivity to ischemia and collagen proliferation and secretion $[3,4]$.
CT-1 releases its biological effects by interacting with the heterodimeric receptor gp130 and the receptor of leukemia inhibitory factor (LIFR), which causes intracellular activation of Janus kinase (Jaks) type I and II, as well as tyrosine kinase. It is shown that the expression of CT- 1 is increased in response to stretching of the heart chambers and increased myocardial stiffness even before the increase in natriuretic peptides [5].

An important role in properties and the expression of CT-1 may belong to the polymorphism of the genes that encode it in particular at position $\mathrm{rs} 8046707 \mathrm{G} / \mathrm{A}$, and according to its biomarker value. Of particular interest is this aspect when using CT-1 not only as a biomarker of CHF, but also to clarify the state of the myocardium in such genetically dependent pathology as $\mathrm{EH}$.

\section{THE AIM}

To improve diagnosis of essential hypertension with LVH and CHF in men citizens of Podillya region in Ukraine by determining the plasma levels of CT- 1 in patients with different CT-1 gene variants.

\section{MATERIALS AND METHODS}

During the study we examined 170 middle-aged male residents of Podillya region. 100 men of the main group 


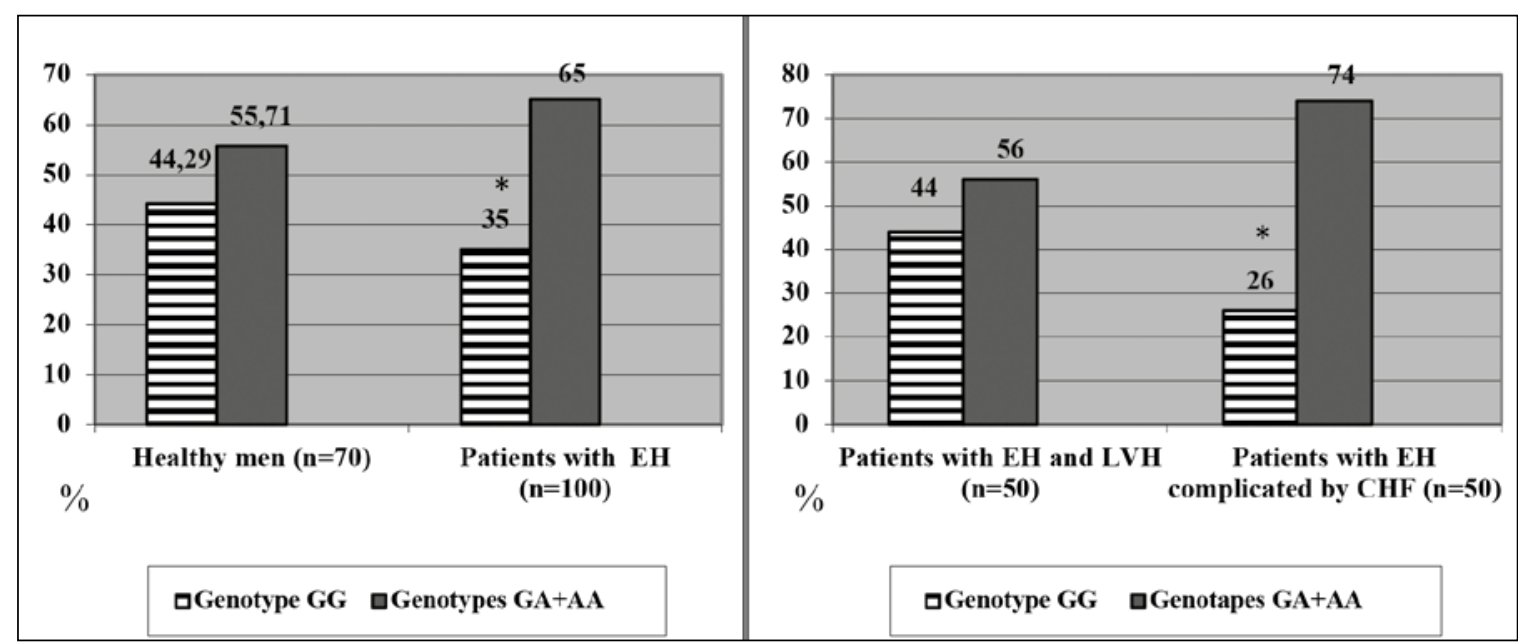

Fig. 1. The distribution of the (T-1 gene genotypes frequencies in men citizens of Podillya region in the healthy patients and the patients with EH and LVH and EH complicated by CHF (\%).

Note: The difference is significant $(p \leq 0,05)$ when compared to: ${ }^{*}-G G$ genotype within each group.

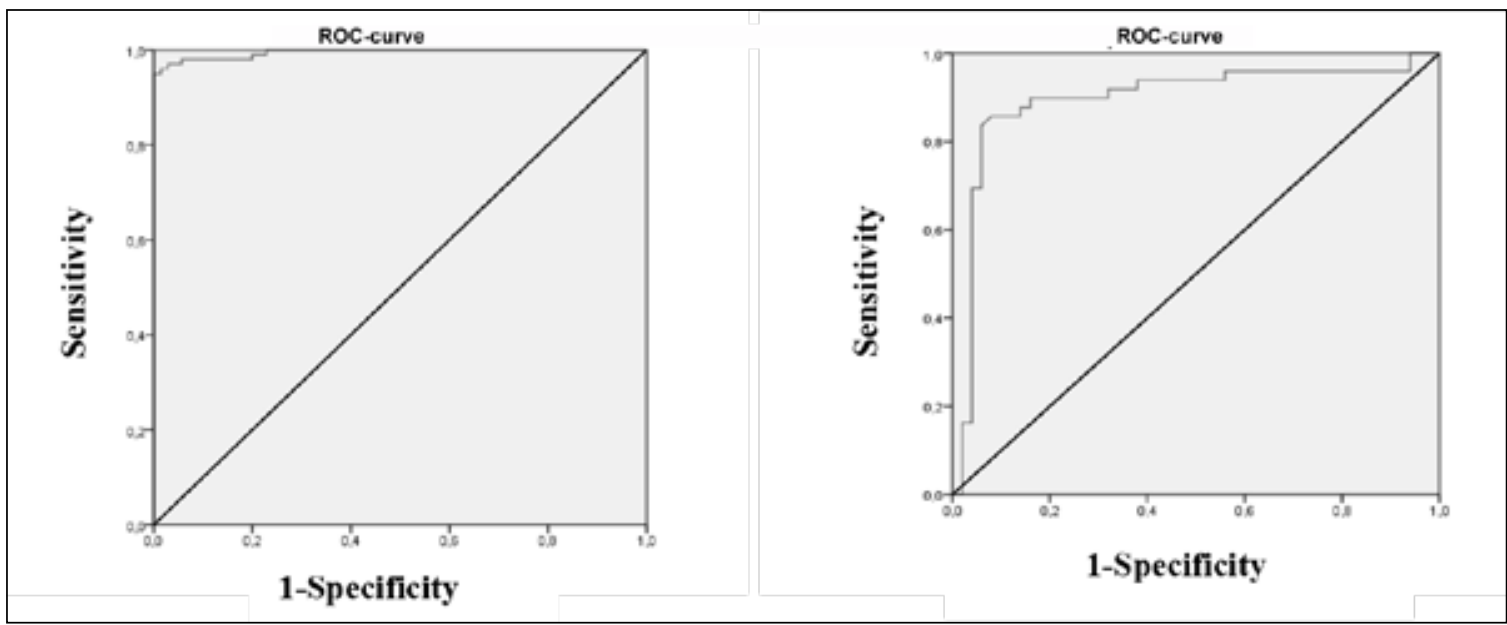

Fig. 2. ROC-curve to determine the cut-off level of CT-1 in blood plasma during the development of LVH in EH and EH complicated by CHF.

with $\mathrm{EH}$ with $\mathrm{LVH}$, whose average age was $50,65 \pm 0,46$ years. Among them, 50 men with EH with LVH (stages 1 and 2), with saved systolic function and CHF I-II classes according to NYHA Classification, whose average age was $50,62 \pm 0,73$ and 50 men with EH complicated by CHF stage IIA, II-III classes according to NYHA Classification, whose average age was $51,86 \pm 0,81.70$ healthy men whose age was $(48,81 \pm 0,78)$ did not differ from patients with $\mathrm{EH}$ and constituted the control group ( $\mathrm{p}>0.05)$.

Exclusion criteria of the study were: secondary hypertension, renal and liver dysfunction, coronary heart disease the onset of which was before $\mathrm{EH}$, endocrine, hematological, neoplastic and autoimmune disorders, patients with $\mathrm{EH}$ complications: myocardial infarction, acute cerebrovascular accident. These diseases were excluded

by collecting complaints, the results of an objective and general clinical examination (including, if necessary, pre-diagnosis of coronary heart disease), as well as a detailed analysis of outpatients' cards.

Genotyping of the CT-1 gene (rs8046707) was conducted using polymerase chain reaction (PCR) after isolation of genomic DNA from white blood cells of venous blood. This study was carried out jointly with the Research Institute of the genetic and immunological bases of pathology and pharmacokinetics "Ukrainian Medical Stomatological Academy" (Poltava, the head is prof. I.P. Kaidashev). The CT-1 concentration in plasma was determined by using ELISA method on enzymelinked immunosorbent analyzer "Humareader single» (Germany).

The mathematical processing was performed on a personal computer using a standard statistical package STATISTICA 10. Structural and functional parameters of the myocardium were evaluated using ultrasound of the heart.

\section{RESULTS}

The frequency distribution of the CT-1 gene genotypes in the men included in the study, residents of the Podillya region of Ukraine, corresponded to the Hardy-Weinberg equilibrium. Because of the relatively small number of patients with the AA genotype, we combined the patients with GA and AA genotypes in the carriers of the genotypes GA +AA. 


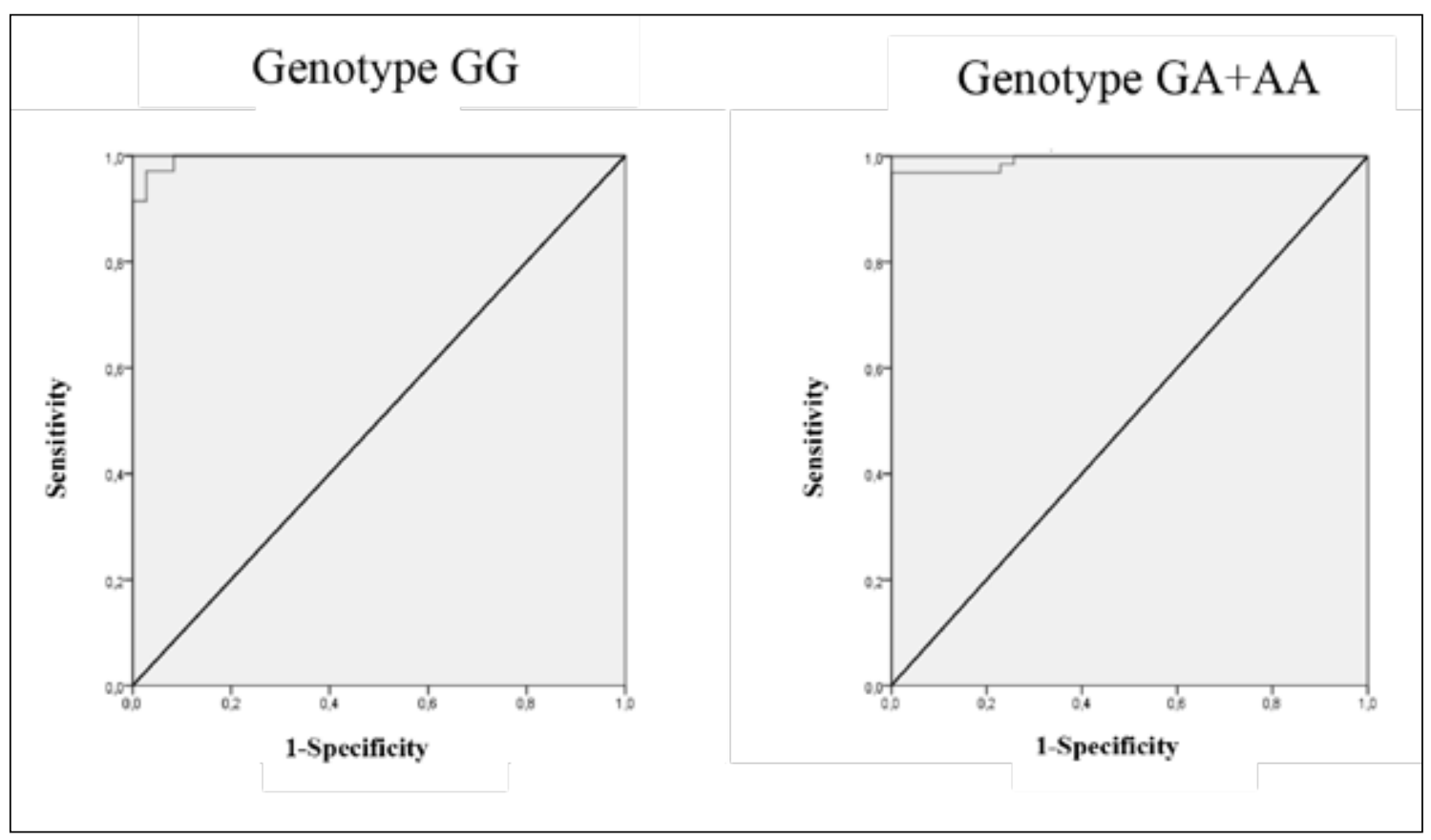

Fig. 3. ROC-curve to determine the cut-off level of CT-1 in blood plasma during the development of LVH in carriers of polymorphic variants of the CT-1 gene.

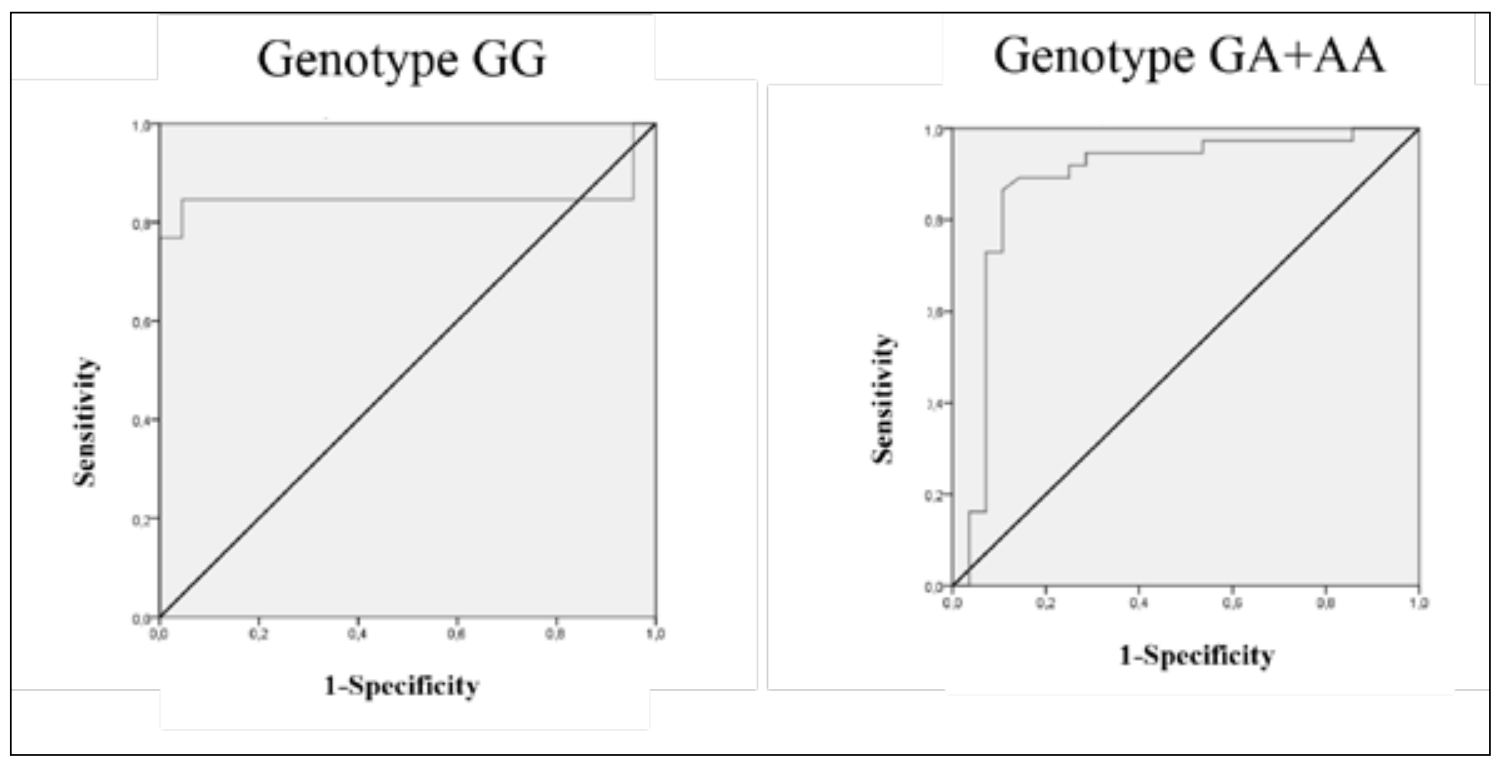

Fig. 4. ROC-curve to determine the cut-off level of CT-1 in blood plasma relative to the development of complicated EH, in carriers of polymorphic variants of the CT-1 gene.

In the control group, there were no significant differences in frequency carriage of the genotype variants of the CT-1 gene ( $p>0.05)$.

In individuals with $\mathrm{EH}$ in general, the frequency of the GG genotype of the CT-1 gene was less than $-35.00 \%(n=$ 65), which is below the pool of genotypes $\mathrm{GA}+\mathrm{AA}-65.00 \%$ $(\mathrm{n}=35)(\mathrm{p}<0.05)$. However, in men with $\mathrm{EH}$ and $\mathrm{LVH}$, the frequency of carriers of the GG genotype is $44.00 \%$ $(\mathrm{n}=22)$, and the pool of genotypes GA + AA is $56.00 \%$ $(\mathrm{n}=28)(\mathrm{p}>0.05)$. Among patients with $\mathrm{EH}$ complicated by CHF stage IIA, the frequency of GG genotype was $26.00 \%$ $(n=13)$, the pool of GA + AA genotypes was $74.00 \%(n=37)$ ( $p<0.05$ ). That is, among the studied contingent with EH reviews the pool of genotypes GA + AA of the CT-1 gene, at the expense of people with CHF. (Fig.1).

In the control groups of GG genotype owners, the main level of CT-1 in blood plasma was lower $-55.77 \pm 2.53 \mathrm{pg} /$ $\mathrm{ml}$ than the carriers of the pool of genotypes GA + AA $92.46 \pm 1.54 \mathrm{pg} / \mathrm{ml}$ and, accordingly, below in men with $\mathrm{EH}$ carriers of different genotypes of the CT-1 gene.

In men with asymptomatic $\mathrm{EH}$ and $\mathrm{EH}$ complicated by CHF, the plasma concentration of CT- 1 is higher in carriers of the pool of genotypes GA + AA, respectively, $272.71 \pm 12.57 \mathrm{pg} / \mathrm{ml}$ and $359.05 \pm 5.79 \mathrm{pg} / \mathrm{ml}(\mathrm{p}<0,05)$ than in carriers of the GG genotype of the CT-1 gene (respectively $189.50 \pm 9.51 \mathrm{pg} / \mathrm{ml}$ and $322.81 \pm 27.01 \mathrm{pg} / \mathrm{ml}$ 
Table 1. Indicators of ROC-analysis for the diagnosis of LVH and CHF in carriers of polymorphic variants of the CT-1 gene.

\begin{tabular}{|c|c|c|c|c|c|}
\hline Group & "Cut off value» & AUC & $\mathbf{p}$ & Sensitivity, \% & Specificity, \% \\
\hline LVH & $\begin{array}{l}122,89 \\
\mathrm{pg} / \mathrm{ml}\end{array}$ & $0,995 \pm 0,003$ & $\mathrm{p}<0,05$ & $95 \%$ & $100 \%$ \\
\hline LVH in carriers of the GG genotype & $\begin{array}{l}113,25 \\
\mathrm{pg} / \mathrm{ml}\end{array}$ & $0,99 \pm 0,004$ & $p<0,05$ & $97,1 \%$ & $98 \%$ \\
\hline $\mathrm{LVH}$ in carriers of the $\mathrm{GA}+\mathrm{AA}$ genotype & $\begin{array}{c}161,5 \\
\mathrm{pg} / \mathrm{ml}\end{array}$ & $0,993 \pm 0,006$ & $\mathrm{p}<0,05$ & $96,9 \%$ & $100 \%$ \\
\hline $\mathrm{CHF}$ & $\begin{array}{l}303,81 \\
\mathrm{pg} / \mathrm{ml}\end{array}$ & $0,895 \pm 0,038$ & $\mathrm{p}<0,05$ & $87,5 \%$ & $92 \%$ \\
\hline CHF in carriers of the GG genotype & $\begin{array}{r}266,955 \\
\mathrm{pg} / \mathrm{ml}\end{array}$ & $0,850 \pm 0,096$ & $\mathrm{p}<0,05$ & $84,6 \%$ & $95 \%$ \\
\hline CHF in carriers of the $G A+A A$ genotype & $\begin{array}{l}323,32 \\
\mathrm{pg} / \mathrm{ml}\end{array}$ & $0,884 \pm 0,050$ & $\mathrm{p}<0,05$ & $86,5 \%$ & $89,2 \%$ \\
\hline
\end{tabular}

$(p<0.05))$. Therefore, in men with the GG genotype and the GA + AA genotype with EH complicated by CHF, the level of the peptide is significantly higher than in persons without signs of cardiovascular pathology and in persons with asymptomatic EH $(\mathrm{p}<0.05)$.

The obtained data allowed us to calculate the boundary levels using ROC-analysis CT-1 in blood plasma for early diagnosis of LVH and $\mathrm{CHF}$ in men with $\mathrm{EH}$, carriers of different variants of the genotype CT-1. This data can be used in the examination of large contingents of the population to identify persons who then need to conduct a full, including ultrasound examination of the heart and have appropriate treatment prescribed in cases of family examination (suspected hereditary pathology) and in expert cases, and in case of impossibility of instrumental examination because of various anatomical defects of the chest.

According to the Swets classification [6], the area under the ROC curve from 0.5 to 0.7 indicates low model accuracy, the model with the area under the ROC curve from 0.7 to 0.9 can be used in practice and the area under the ROC-curve above 0.9 characterizes highly accurate model. Based on the ROC-curve, which is presented in Fig. 2, sensitivity and specificity for different boundary points were calculated.

The area under the AUC curve according to ROC-analysis for the determination of CT-1 in blood plasma in the presence of $\mathrm{EH}$ and $\mathrm{LVH}$ of varying severity is $0.995 \pm$ 0.003 [95\% CI from 0.988 to 1.00 ; ] which indicates the excellent quality of the obtained models. The cut-off point equal to $\geq 122,89 \mathrm{pg} / \mathrm{ml} 89 \%$ sensitivity and $92 \%$ specificity with an AUC equal to $93 \%$ This calculation allows to establish the cut-off level of CT-1 in blood plasma (sensitivity-95\%, specificity-100\%) in such a structural state of the myocardium as LVH. The area under the AUC curve according to ROC analysis for CT- 1 is $0.895 \pm 0.038$ [ $95 \%$ CI from 0.822 to $0.969 ;$; , which indicates a very good quality of the obtained model. The obtained data indicate that the level of CT-1 in blood plasma $\geq 303.81 \mathrm{pg} / \mathrm{ml}$ (sensitivity $-85.7 \%$, specificity-92\%) can be considered as a boundary for the diagnosis of $\mathrm{EH}$ complicated by $\mathrm{CHF}$.

However, it is also necessary to take into account possi- ble deviations from the presented parameters in carriers of different variants of the genotype of the CT-1 gene, because the plasma concentrations of this biomarker in the respective subgroups differ.

The area under the AUC curve according to ROC analysis to determine the level of CT-1 in blood plasma in GG homozygotes is $0.99 \pm 0.004$ [ $95 \% \mathrm{CI}$ from 0.988 to 1,000 ;], in carriers of the pool of genotypes GA + AA ( Fig. 3) - 0.993 \pm 0.006 [ $95 \%$ CI from 0.981 to 1,000 ; ] which indicates the excellent quality of the obtained models. The cut- off CT- 1 in blood plasma for the diagnosis of LVH in carriers of the GG genotype is $\geq 113,255 \mathrm{pg} / \mathrm{ml}$ (sensitivity - 97.1\%, specificity-98\%) and in carriers of GA+AA genotype $\geq$ $161.5 \mathrm{pg} / \mathrm{ml}$ (sensitivity - 96, 9\%, specificity - 100\%).

The area under the AUC curve according to ROC analysis for the determination of CT- 1 in blood plasma in carriers of the GG genotype is $0.850 \pm 0.096$ [ $95 \% \mathrm{CI}$ from 0.662 to $1,000 ;]$, in carriers of the GA + AA genotype pool - 0.884 \pm 0.050 [ $95 \%$ CI from 0.785 to 0.982 ;] (Fig. 4) which indicates a very good quality of the obtained model. These data indicate that in male homozygotes GG the level of CT-1 in blood plasma $\geq 266,955 \mathrm{pg} / \mathrm{ml}$ (sensitivity - 84.6\%, specificity - 95\%), and in carriers of the genotype GA + AA $\geq 323.32 \mathrm{pg} / \mathrm{ml}$ (sensitivity- $86.5 \%$, specificity - 89.2\%) allows to diagnose CHF.

The data presented in table 1 shows that the obtained results have a very good quality of the model, sensitivity and specificity for the diagnosis of $\mathrm{LVH}$ on the background of $\mathrm{EH}$ and $\mathrm{CHF}$ in men.

\section{DISCUSSION}

Thus, among 40 to 60 years old men, residents of the Podillia region in Ukraine who are patients with EH the frequency of registration of the pool of genotypes GA + AA was higher than in the group of patients with $\mathrm{EH}$ heterozygotes GG.

In a study done by Lutz $S Z$, Franck $\mathrm{O}$ et al. in the German population, it was found that the GA genotype is most common among Germans [7]. In both German and Ukrainian populations, the AA genotype is rarely identified. 
In the study of plasma concentrations of CT-1 it was found that men with $\mathrm{EH}$ and $\mathrm{LVH}$ have significantly higher level those in the control group and in turn levels than persons with $\mathrm{EH}$, complicated by $\mathrm{CHF}(\mathrm{p}<0,05)$. In men with $\mathrm{EH}$ of varying severity, the plasma concentration of CT- 1 is significantly higher in carriers of the GA + AA genotype of the CT-1 gene. $(\mathrm{p}<0.05)$. In a meta-analysis conducted by K. Song, the plasma concentration of CT-1 not only increases with $\mathrm{EH}$, but also has a prognostic value for the development of CHF [8]. In a study conducted by Kolesnik M.Yu. among the residents of Ukraine there was an increase in the concentration of the marker depending on the severity of impaired glucose metabolism. The results were such that in men with $\mathrm{EH}$ without impaired glucose metabolism, the concentration of the marker was 176.1 (106.5-436.2) pg / $\mathrm{ml}$, in the presence of insulin resistance in combination with $\mathrm{EH}$, the level of CT-1 in blood plasma $282.2(119.5-650.2) \mathrm{pg} / \mathrm{ml}$ [9]. The study clarified the diagnostic limits for the confirmation of LVH in EH and CHF.

\section{CONCLUSIONS}

In 40-60 years old male residents of Podillya who were patients with $\mathrm{EH}$ the frequency of the pool of genotypes $\mathrm{GA}+\mathrm{AA}$ is higher than the genotype GG $(\mathrm{p}<0.05)$ due to patients with CHF.

Plasma CT-1 levels $\geq 122,895 \mathrm{pg} / \mathrm{ml}$ can be used for early diagnosis of myocardial changes such as $\mathrm{LVH}$, and the cut-off level is $\geq 303.81 \mathrm{pg} / \mathrm{ml}$ (sensitivity $85.7 \%$, specificity 92\%) for screening diagnosis of $\mathrm{CHF}$.

\section{REFERENCES}

1. Radchenko G.D, Torbas 0.0 , Sirenko Y.M. Predictors of high central blood pressure in young with isolated systolic hypertension. Vasc Health Risk Manag. 2016;12:321-328. https://doi:10.2147/VHRM.S97304.

2. Andersson C., Johnson, A.D., Benjamin E.J. et al. 70-year legacy of the Framingham Heart Study. Nat Rev Cardiol 2019;16:687-698. https:// doi.org/10.1038/s41569-019-0202-5.

3. Stephens J., Ravussin E., White U. The Expression of Adipose TissueDerived Cardiotrophin-1 in Humans with Obesity. Biology (Basel). 2019;8(2):24. https://doi.org/10.3390/biology8020024.

4. Watanabe T., Konii H., Sato K. Emerging Roles of Cardiotrophin- 1 in the Pathogenesis and Biomarker of Atherosclerosis. J. 2018; 1: 94-105.

5. Miteva K., Baptista D., Montecucco F. et al. Cardiotrophin-1 Deficiency Abrogates Atherosclerosis Progression. Sci Rep. 2020;10:5791. https:// doi.org/10.1038/s41598-020-62596-6.
6. Krupinski EA. Receiver Operating Characteristic (ROC) Analysis. Frontline Learning Research. 2017; 5(3):31-42.

7. Lutz S., Franck 0., Böhm A. et al. Common Genetic Variation in the Human CTF1 Locus, Encoding Cardiotrophin-1, Determines Insulin Sensitivity. PloS one. 2014; 9(7):e100391 D0I: 10.1371/journal. pone.01003919.

8. Song K, Wang S, Huang B, et al. Plasma cardiotrophin-1 levels are associated with hypertensive heart disease: a meta-analysis. J Clin Hypertens (Greenwich). 2014;16(9):686-692. doi:10.1111/jch.12376

9. Kolesnik M.Yu. «Dinamika biomarkeriv kardial'nogo remodelyuvannya kardiotrofina- 1 ta aneksinu v v cholovikiv z arterial'noyu gipertenzieyu pid vplivom kombinovanoï terapiiì [Dynamics of biomarkers of cardiac remodelling of cardiotrophin-1 and annexin $v$ in male patients with arterial hypertension under combined therapy] Actual Problems of the Modern Medicine:Bulletin of Ukrainian Medical Stomatological Academy. 2015; 15(1):110-115. (In Ukrainian)

\section{ORCID and contributorship:}

Maryna O. Matokhniuk: 0000-0001-5968-0512 $2^{A, B, C, D}$

Oleksandr V. Limanskiy: 0000-0002-5725-1340 ${ }^{A, B}$

Olena V. Maiko: 0000-0002-6392-3289 ${ }^{A, E}$

Vadym M. Zhebel: 0000-0002-6542-9313 ${ }^{A, E, F}$

Oleksandra K. Shevchuk: 0000-0001-6795-5969

Irina K. Palii: 0000-0002-8000-1702 ${ }^{A, E}$

\section{Conflict of interest:}

The Authors declare no conflict of interest.

\section{CORRESPONDING AUTHOR Maryna 0. Matokhniuk \\ Vinnytsia National Pirogov Memorial Medical University \\ 56 Pirogov Str., Vinnytsia, Ukraine \\ tel: +380682137788 \\ e-mail:marina.s.a8604@gmail.com}

Received: 11.09 .2020

Accepted: 08.01.2021

A-Work concept and design, $\mathbf{B}$ - Data collection and analysis, $\mathbf{C}$ - Responsibility for statistical analysis,
D-Writing the article, E-Critical review, F- Final approval of the article 